\title{
The Medicinal Plant of Genus Paronychia and the Karyotype Analysis of Paronychia adalia
}

\section{Halil Erhan EROĞLU ${ }^{1}$, Hülya DOĞAN², Derya ALTAY ${ }^{*}$, Ümit BUDAK ${ }^{4}$}

\author{
${ }^{1}$ Department of Biology, Faculty of Science and Art, Bozok University, Yozgat, Turkey \\ ${ }^{2}$ Department of Seed Science, Vocational School, Bozok University, Yozgat, Turkey \\ ${ }^{3}$ Department of Biology, Graduate School of Natural and Applied Sciences, Bozok University, Yozgat, Turkey \\ ${ }^{4}$ Department of Biology, Faculty of Science and Art, Bozok University, Yozgat, Turkey,
}

Received: 28 April 2017 - Accepted: 03 June 2017

\begin{abstract}
The genus Paronychia Miller is placed in the family Caryophyllaceae. It contains approximately 110 species of annual or perennial found all over the world except Southern Africa, Southeast Asia. Genus Paronychia is known as Algerian tea in the world. In our country, the genus commonly known as et yaran, kepek otu and dolama otu is used as medicinal tea because of relieving inflammation between the hands and toes, aphrodisiac, diuretic and blood purifier. Antimicrobial and antioxidant properties of the genus are known. The chromosome number is $2 n=36$ in many species of Paronychia. But there are various chromosome numbers as $2 n=10,14,16$, 18 and 28. In this study, the chromosome number of $P$. adalia Chaudhri was reported for the first time. The chromosome number and karyotype formula are $2 \mathrm{n}=2 \mathrm{x}=36=34 \mathrm{~m}+2 \mathrm{sm}$. Total haploid length, centromeric index and karyotype asymmetry were calculated with detailed chromosomal measurements.
\end{abstract}

Keywords: Paronychia, medicinal plant, chromosome.

\section{INTRODUCTION}

The genus Paronychia Miller is placed in the family Caryophyllaceae. It contains approximately 110 species of annual or perennial widespread around the world except Southeast Asia and Southern Africa. It contains total of 41 taxa as 29 species, five subspecies and seven varieties in Turkey, too. In other words, the species in our country cover approximately $35 \%$ of the world Paronychia. There are 28 endemic taxa for our country and the rate of endemism of the genus is $68.3 \%$. The genus, which was previously in the family Illecebraceae, has now been taken into the subfamily Paronychioideae in the family Caryophyllaceae with recent studies [1].

Genus Paronychia is known as Algerian tea in the world. In our country, the genus commonly known as et yaran, kepek otu and dolama otu is used as medicinal tea because of relieving inflammation between the hands and toes, aphrodisiac, diuretic and blood purifier. Antimicrobial and antioxidant properties of the genus are known [2].

\footnotetext{
*Corresponding Author E-mail: hulya.dogan@bozok.edu.tr
} 
Paronychia adalia Chaudhri is a plant with white coloured and small flowers. It is an endemic species in Turkey and grows at rocky-stone areas, limestone rocks and forest openings. No data available about the biological activity and chromosomal data of $P$. adalia in literature.

In this study, we examined the karyotype analyses of $P$. adalia collected from Mediterranean region, Turkey (Figure 1). The diploid chromosome number is $2 n=36$ in many taxa of Paronychia [3-5]. But there are different chromosome numbers as $2 n=10$ ( $P$. echinulata Chater), $2 n=14$ (P. polygonifolia (Vill.) DC.), $2 n=16$ (P. suffruticosa (L.) DC.), $2 n=18$ (P. aretioides Pourr. ex DC., $P$. kurdica Boiss., $P$. macrosepala Boiss., $P$. caespitosa Stapf), $2 n=$ 28 ( $P$. argentea Lam.), $2 n=32$ ( $P$. pulvinata A. Gray) and $2 n=64$ (P. sessiliflora Nutt.) [3-5]. These species are only given the diploid chromosome number in the studies. There is not the data regarding chromosomal measurements. The cytogenetic characters, especially chromosome size, karyotype formula and chromosome asymmetry are important characters as chromosome number. These characters are also important to elucidate the origin, speciation and phylogenetic relationships of species and genus [6-7].

\section{MATERIAL and METHODS}

Collection information regarding the species is listed below.

Paroncyhia adalia - TURKEY. Antalya: Elmal1, Susuz mountain, close to the top, rocky slopes, 2080 m, 01-VIII-2013, Budak 2756 \& Hamzaoğlu (Bozok Hb.).

The cytogenetic procedure is listed below, respectively. (i) germination at room temperature, (ii) pretreatment with $\alpha$-monobromonaphthalene, (iii) fixation with Carnoy's fixative, (iv) hydrolysis with $1 \mathrm{~N} \mathrm{HCl}$, (v) staining with aceto orcein, (vi) preparation with acetic acid, (vi) permanent preparation with DPX [6-7].

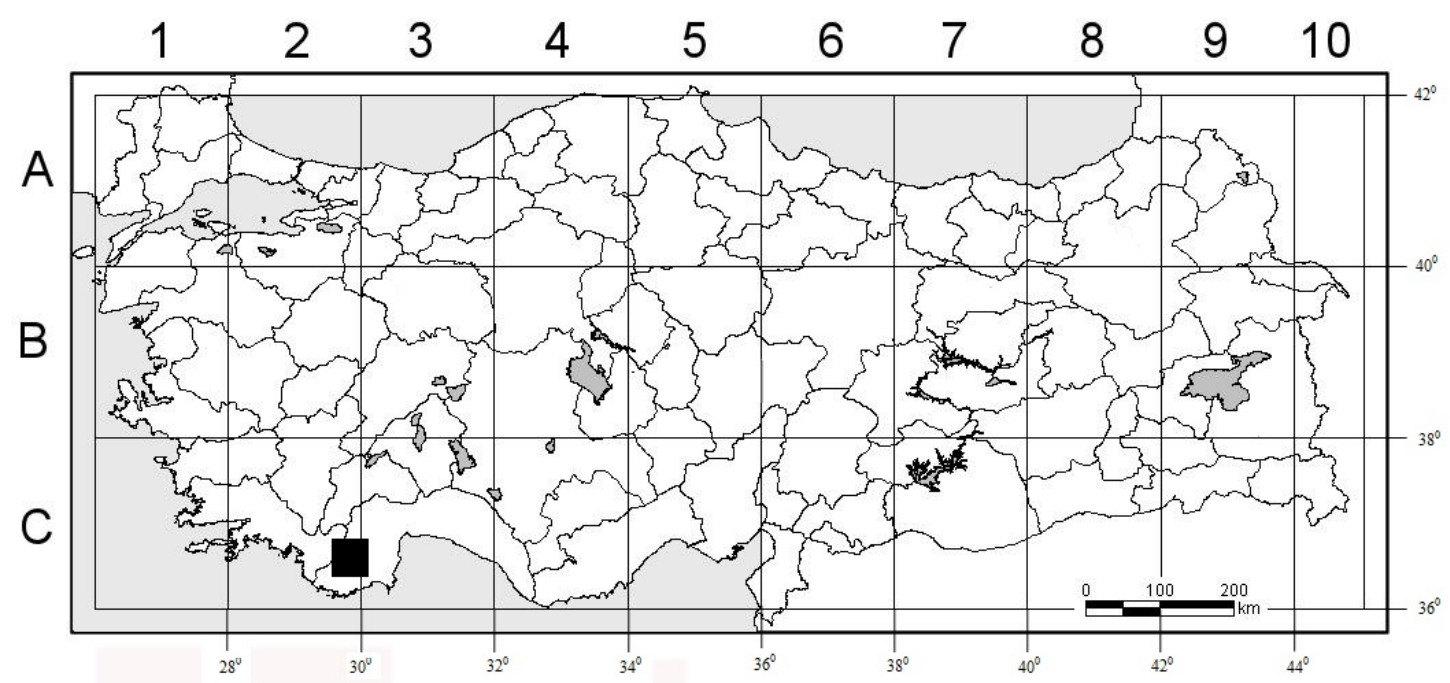

Figure 1. Distribution in Turkey of Paronychia adalia

The chromosomes were photographed with Olympus DP72 camera and measured with KaryoType software [8]. Chromosome classifications were made according to the Levan et al. [9]. The parameters were calculated to characterize of karyotypes numerically: long arm length of chromosome (LAL), short arm length of chromosome (SAL), total chromosome length $(\mathrm{TCL})=[\mathrm{L}+\mathrm{S}]$, arm ratio of chromosome $(\mathrm{AR})=[\mathrm{L} / \mathrm{S}]$ and centromeric index $(\mathrm{CI})=[\mathrm{S} /(\mathrm{L}$ $+S) \times 100$ ]. The ideogram was drawn based on length of chromosome size (arranged large to small). Karyotype asymmetries were estimated by $\mathrm{M}_{\mathrm{CA}}$ [10] and $\mathrm{CV}_{\mathrm{CL}}$ [11]. 


\section{RESULTS}

The somatic metaphase chromosomes and monoploid ideogram of Paronychia adalia are given in Figure 2 and 3. The measurement data of chromosomes are given in Table 1. Somatic metaphases analysis showed that the diploid chromosome number of $P$. adalia is $2 n=2 \mathrm{x}=36$. The karyotype formula is $2 n=2 \mathrm{x}=36=34 \mathrm{~m}+2 \mathrm{sm}$. All chromosomes are median type outside sub-median chromosome 8 . No satellite was observed in the chromosomes.

The chromosome lengths range between 0.93 and $2.55 \mu \mathrm{m}$. The chromosome 1 has the longest both long arm length $(1.35 \mu \mathrm{m})$ and short arm length $1.20 \mu \mathrm{m})$. The chromosome 18 has the shortest both long arm length $(0.57 \mu \mathrm{m})$ and short arm length $0.36 \mu \mathrm{m})$. The arm ratio of chromosome 8 is quite high, unlike the arm ratio of chromosome 2, 5 and 6 are quite low.

Total haploid length and mean haploid length are 27.34 and $1.52 \mu \mathrm{m}$, respectively. The centromeric indexes range between 31.29 and 49.09. The low centromeric index is characterized with median zone, unlike very high centromeric index is characterized with telocentric zone.

The $\mathrm{M}_{\mathrm{CA}}$ and $\mathrm{CV}_{\mathrm{CL}}$ values are 12.20 and 27.24, respectively. The $\mathrm{M}_{\mathrm{CA}}$ and $\mathrm{CV}_{\mathrm{CL}}$ decrease with decreasing asymmetry. The centromeric position changes in intrachromosomal karyotype asymmetry $\left(\mathrm{M}_{\mathrm{CA}}\right)$. The $\mathrm{M}_{\mathrm{CA}}$ varies between 0 (most symmetrical) and 100 (most asymmetric). Besides, the chromosome sizes are quite different in interchromosomal karyotype asymmetry $\left(\mathrm{CV}_{\mathrm{CL}}\right)$. The $\mathrm{CV}_{\mathrm{CL}}$ varies between 0 and 100 .

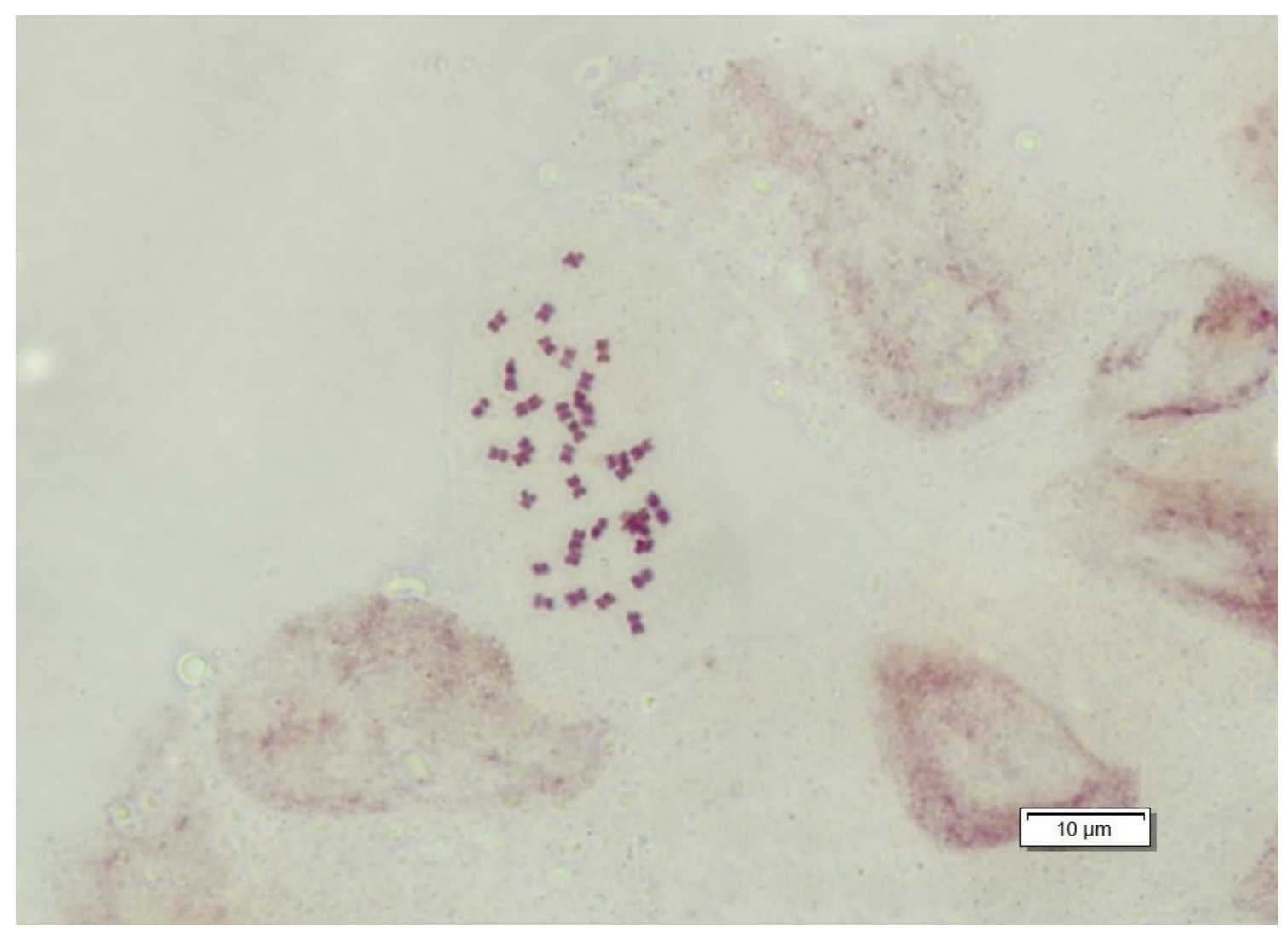

Figure 2. Somatic metaphase chromosomes of Paroncyhia adalia. 
Table 1. The chromosomal data of Paronychia adalia.

\begin{tabular}{|c|c|c|c|c|c|c|}
\hline $\begin{array}{c}\text { Chromosome } \\
\text { Pair }\end{array}$ & $\begin{array}{l}\text { TCL } \\
(\mu \mathrm{m})\end{array}$ & $\begin{array}{c}\text { LAL } \\
(\mu \mathrm{m})\end{array}$ & $\begin{array}{c}\text { SAL } \\
(\mu \mathrm{m})\end{array}$ & AR & Type & CI \\
\hline 1 & 2.55 & 1.35 & 1.20 & 1.12 & $\mathrm{~m}$ & 47.06 \\
\hline 2 & 2.20 & 1.12 & 1.08 & 1.04 & $\mathrm{~m}$ & 49.09 \\
\hline 3 & 1.87 & 1.05 & 0.82 & 1.28 & $\mathrm{~m}$ & 43.85 \\
\hline 4 & 1.75 & 1.05 & 0.70 & 1.50 & $\mathrm{~m}$ & 40.00 \\
\hline 5 & 1.73 & 0.90 & 0.83 & 1.08 & $\mathrm{~m}$ & 47.98 \\
\hline 6 & 1.66 & 0.86 & 0.80 & 1.07 & $\mathrm{~m}$ & 48.19 \\
\hline 7 & 1.64 & 0.87 & 0.77 & 1.13 & $\mathrm{~m}$ & 46.95 \\
\hline 8 & 1.63 & 1.12 & 0.51 & 2.20 & $\mathrm{sm}$ & 31.29 \\
\hline 9 & 1.51 & 0.82 & 0.69 & 1.19 & $\mathrm{~m}$ & 45.70 \\
\hline 10 & 1.48 & 0.77 & 0.71 & 1.08 & $\mathrm{~m}$ & 47.97 \\
\hline 11 & 1.32 & 0.70 & 0.62 & 1.13 & $\mathrm{~m}$ & 46.97 \\
\hline 12 & 1.30 & 0.71 & 0.59 & 1.20 & $\mathrm{~m}$ & 45.38 \\
\hline 13 & 1.22 & 0.70 & 0.52 & 1.35 & $\mathrm{~m}$ & 42.62 \\
\hline 14 & 1.21 & 0.65 & 0.56 & 1.16 & $\mathrm{~m}$ & 46.28 \\
\hline 15 & 1.14 & 0.69 & 0.45 & 1.53 & $\mathrm{~m}$ & 39.47 \\
\hline 16 & 1.11 & 0.65 & 0.46 & 1.41 & $\mathrm{~m}$ & 41.44 \\
\hline 17 & 1.09 & 0.64 & 0.45 & 1.42 & $\mathrm{~m}$ & 41.28 \\
\hline 18 & 0.93 & 0.57 & 0.36 & 1.58 & $\mathrm{~m}$ & 38.71 \\
\hline
\end{tabular}

Abbreviations: TCL, total chromosome length; LAL, long arm length; SAL, short arm length; AR, arm ratio; CI, centromeric index; m, median; sm, sub-median.

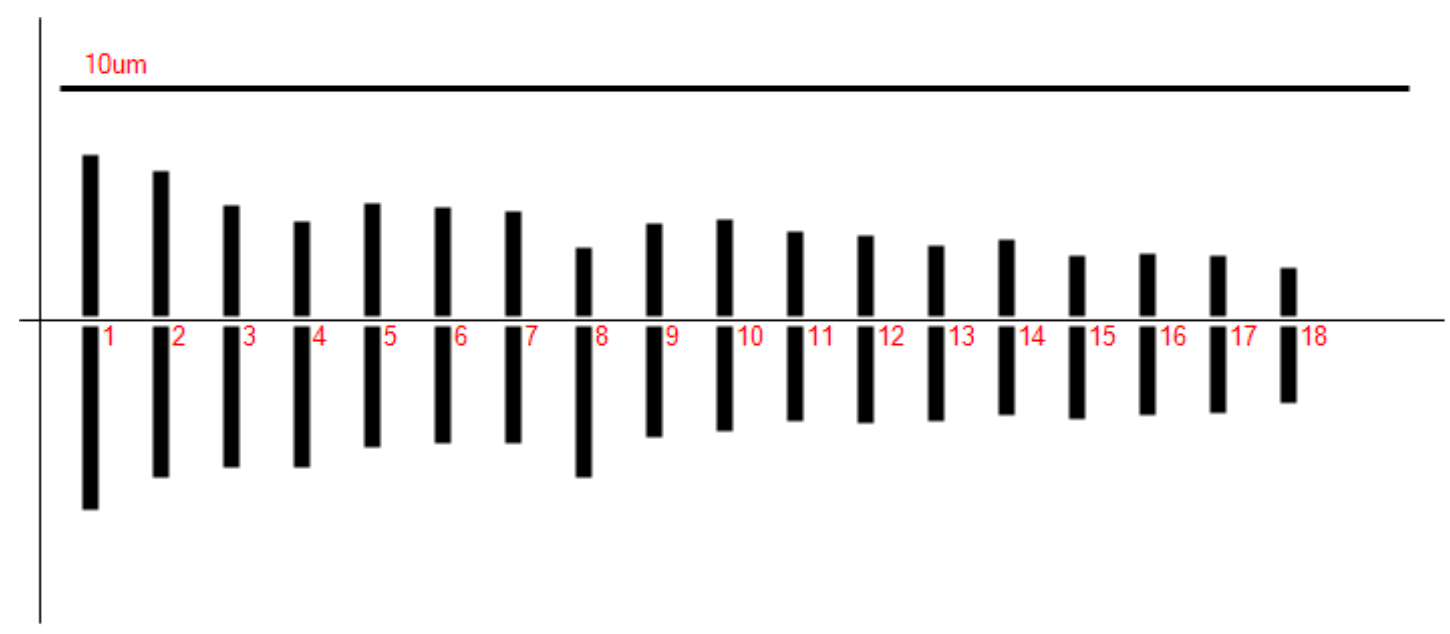

Figure 3. Ideogram of Paroncyhia adalia.

\section{DISCUSSION}

The chromosome number of Paroncyhia adalia is $2 \mathrm{n}=36$. The species has small chromosomes between $0.93-2.55 \mu \mathrm{m}$. There is very little variation between chromosomes (Table 1). It reported that the chromosome number was $2 \mathrm{n}=36$ in many species of Paronychia. But the genus was showed different chromosome numbers as $2 \mathrm{n}=10,14,16,18$ and 28 [3-5].

Karyotype asymmetry is an important parameter for karyotype studies [12-13]. The $\mathrm{M}_{\mathrm{CA}}$ and $\mathrm{CV}_{\mathrm{CL}}$ are the most reliable values among karyotype asymmetry indexes [10]. The $\mathrm{M}_{\mathrm{CA}}$ and $\mathrm{CV}_{\mathrm{CL}}$ values of Paroncyhia adalia are 12.20 and 27.24, respectively. According to these values, the karyotype is quite symmetrical. 
In the study, the karyological data of Paroncyhia adalia was showed for the first time. The karyological data are not distinctive or connective characters in plant taxonomy; however they can support these characters. The chromosomal variations can support to diversification of the species [6-7]. There are still many taxa unknown chromosomal data in genus Paroncyhia. More chromosomal data are needed to contribute to the cytotaxonomy of Paroncyhia. With future studies, the chromosomal data of other taxa will be determined.

\section{Conflict of Interests}

Authors declare that there is no conflict of interests.

\section{REFERENCES}

[1] Chaudhri, M. N. (1968). A revision of the Paronychiinae. Mededelingen van het Botanisch Museum en Herbarium van de Rijksuniversiteit te Utrecht, 285(1), 3-440.

[2] Albayrak, S., \& Aksoy, A. (2010). In vitro antioxidant and antimicrobial properties of Paronychia mughlaei Chaudhri. Acta Botanica Gallica, 157(3), 411-418.

[3] Çelebioğlu, T., \& Favarger, C. (1993). Mediterranean chromosome number reports 3 (125166), Flora Mediterranea, 3, 323-333.

[4] Diosdado, J.C., \& Pastor, J. (1994). Estudio cariologico del gĕnero Paronychia Miller (Caryophyllaceae) en Andaluč̌a (Espana). Acta Botanica Malacitana, 19, 89-95.

[5] Runemark, H. (1996). Mediterranean chromosome number reports 6 (590-678), Flora Mediterranea. 6, 223-243.

[6] Şahin, E., Eroğlu, H.E., Hamzaoğlu, E., \& Koç, M. (2016). Karyotype analysis of four species of Dianthus section Fimbriati (Caryophyllaceae, Sileneae). Caryologia, 69, 267272.

[7] Yüce, O., Eroğlu, H.E., Koç, M., \& Hamzaoğlu, E. (2016) Karyotype analysis of Minuartia mesogitana subsp. mesogitana and Minuartia elmalia (Caryophyllaceae, Alsinoideae). Boletín de la Sociedad Argentina de Botánica, 51, 463-467.

[8] Altınordu, F., Peruzzi, L., Yu, Y., \& He, X.J. (2016). A tool for the analysis of chromosomes: KaryoType. Taxon, 65, 586-592.

[9] Levan, A.K., Fredga, K., \& Sandberg, A.A. (1964). Nomenclature for centromeric position on chromosomes. Hereditas, 52, 201-220.

[10] Peruzzi, L., \& Eroğlu, H.E. (2013). Karyotype asymmetry: again, how to measure and what to measure?. Comparative Cytogenetics, 7, 1-9.

[11] Paszko, B. (2006). A critical review and a new proposal of karyotype asymmetry indices. Plant Systematics and Evolution, 258, 39-48.

[12] Eroğlu, H.E. (2015). Which chromosomes are subtelocentric or acrocentric? A new karyotype symmetry/asymmetry index, Caryologia, 68, 239-245.

[13] Eroğlu, H.E., Şimşek, N., Koç, M., \& Hamzaoğlu, E. (2013). Karyotype analysis of some Minuartia L. (Caryophyllaceae) taxa. Plant Systematics and Evolution, 299, 67-73. 